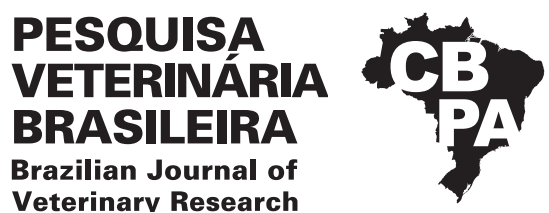

\title{
Predisposition to acute pancreatitis in dogs with severe acute renal failure ${ }^{1}$
}

INDEX TERMS: Predisposition, acute pancreatitis, acute renal insufficiency, beta-hydroxybutyrate, canine pancreatic lipase, dogs.

\begin{abstract}
RESUMO.- [Predisposição à pancreatite aguda em cães com insuficiência renal aguda grave.] 0 portador de insuficiência renal aguda é um paciente que, muitas vezes, encontra-se sob importante condição de balanço energético negativo, gerando alterações metabólicas que predispõem a complicações. 0 objetivo deste estudo foi avaliar parâmetros laboratoriais de trinta cães com insuficiência renal aguda grave, quanto a possibilidade de desenvolvimento de pancreatite aguda em função do balanço energético negativo, e relacioná-los ao grau de gravidade da insuficiência renal. As concentrações séricas de ureia, creatinina, betahidroxibutirato, triglicérides, amilase, lipase total e lipase pancreática canina foram comparadas entre o grupo de cães
\end{abstract}

\footnotetext{
${ }^{1}$ Received on February 9, 2021.

Accepted for publication on February 21, 2021.

${ }^{2} \mathrm{PhD}$ Student in Animal Science, Escola de Veterinária, Universidade Federal de Minas Gerais (UFMG), Av. Antônio Carlos 6627, Cx. Postal 567, Pampulha, Belo Horizonte, MG 31270-901, Brazil. *Corresponding author: danielabastos@vetufmg.edu.br

${ }^{3}$ Associate Professor III, Escola de Veterinária, Universidade Federal de Minas Gerais (UFMG), Av. Antônio Carlos 6627, Cx. Postal 567, Pampulha, Belo Horizonte, MG 31270-901, Brazil. E-mail: juliocambraia@gmail.com

${ }^{4}$ Masters student in Animal Science, Escola de Veterinária, Universidade Federal de Minas Gerais (UFMG), Av. Antônio Carlos 6627, Cx. Postal 567, Pampulha,
}

hígidos e o de cães doentes. Observou-se maior concentração sérica de betahidroxibutirato e maior atividade das enzimas pancreáticas, especialmente da lipase pancreática canina, além de forte correlação entre esta última e a concentração sérica de creatinina, demonstrando a ocorrência de pancreatite aguda em pacientes com insuficiência renal aguda grave. Verificou-se também que quanto mais grave é a insuficiência renal, maior é a predisposição à pancreatite aguda.

TERMOS DE INDEXAÇÃO: Predisposição, pancreatite aguda, insuficiência renal aguda, cão, caninos, betahidroxibutirato, lipase pancreática canina.

Belo Horizonte, MG 31270-901, Brazil. E-mails: m.ceregatti@icloud.com, jufavati@gmail.com, claracmpessoa@gmail.com

${ }^{5}$ Masters in Animal Science, Escola de Veterinária, Universidade Federal de Minas Gerais (UFMG), Av. Antônio Carlos 6627, Cx. Postal 567, Pampulha, Belo Horizonte, MG 31270-901, Brazil. E-mail: karinaroquesilva@gmail.com

${ }^{6} \mathrm{PhD}$ Student in Animal Science, Escola de Veterinária, Universidade Federal de Minas Gerais (UFMG), Av. Antônio Carlos 6627, Cx. Postal 567, Pampulha, Belo Horizonte, MG 31270-901, Brazil. E-mail: ndintensivismo@gmail.com

${ }^{7}$ Associate Professor I, Escola de Veterinária, Universidade Federal de Minas Gerais (UFMG), Av. Antônio Carlos 6627, Cx. Postal 567, Pampulha, Belo Horizonte, MG 31270-901, Brazil. E-mail: fabiola.ufmg@gmail.com 


\section{INTRODUCTION}

Acute renal failure (ARF) is characterized by an abrupt and persistent decrease in one or more kidney functions due to some primary cause. It is characterized by a decrease in the glomerular filtration rate, resulting in an accumulation of metabolic residues, and the inability to regulate hydro electrolyte and acid-base balance (Veado et al. 2014). Over time, if the primary cause of ARF is not identified and treated, there is severe systemic impairment due to metabolic changes and disorder of homeostasis, often leading to death (Ross 2011, Veado et al. 2014, Carvalho 2015). According to Cowgill (2016), there are five degrees of ARF, based on creatinine serum concentration: Grade I $<1.6 \mathrm{mg} / \mathrm{dL}$, Grade II between 1.7 and $2.5 \mathrm{mg} / \mathrm{dL}$, Grade III between 2.6 and $5.0 \mathrm{mg} / \mathrm{dL}$, Grade IV between 5.1 and $10.0 \mathrm{mg} / \mathrm{dL}$, and Grade $V>10 \mathrm{mg} / \mathrm{dL}$.

In addition to the challenge of identifying the primary cause and clinically stabilizing these patients, adequate nutritional support is another difficulty encountered, usually due to anorexia, vomiting, and hypermetabolism, which aggravates the negative energy balance state (Li et al. 2013). With a negative energy balance, there is a deficiency of glucose in the cells and, consequently, stimulation of hepatic gluconeogenesis. This new condition promotes production of ketone bodies, which leads to increased serum concentrations of $\beta$-hydroxybutyrate (BHB) (Palomba \& Okada 2010). BHB is the predominant ketone body produced during prolonged fasting and reflects the use of fat as an energy source. Thus, it is considered that an increase in the serum concentration of BHB is related to the negative energy balance due to fat catabolism (Gorman et al. 2016). It is a marker of diabetes mellitus, diabetic ketoacidosis, chronic kidney disease, acute pancreatitis in animals, as well as of hyperthyroidism and hepatic lipidosis in cats (Gorman et al. 2016, Hurrell et al. 2016, Claus et al. 2017). In critically ill patients with ARF, there is also a higher risk of hypertriglyceridemia, both due to mobilization of fat from adipose tissue and due to compromise of triglyceride clearance (Wiesen et al. 2011). All these metabolic changes predispose the individual to several complications, including acute pancreatitis (AP). There haven't been studies in the researched literature regarding the chance of developing AP in patients with severe ARF.

AP is a sudden onset of inflammation of the pancreas, which is usually aseptic, and is characterized by edema and necrosis (Van Den Bossche et al. 2010), with variable involvement of peripancreatic organs and tissues, and which may affect distant organs (Silva \& Ponce 2015). AP begins with the intra-acinar activation of trypsinogen into trypsin, which under normal conditions would only occur in the intestine. Trypsin, in turn, activates other enzymes in a cascade, which may cause autodigestion of the pancreas and adjacent tissues, with a consequent inflammatory reaction. The factors involved in intrapancreatic activation of these enzymes are not completely known (Van Den Bossche et al. 2010, Silva \& Ponce 2015), but it is known that conditions, such as hyperlipidemia, hypercalcemia, medications, toxins, improper diet, malnutrition, trauma, ischemia followed by reperfusion, endocrinopathies, and infections may predispose to AP (Silva \& Ponce 2015). Its diagnosis is challenging, since the clinical characteristics are variable and are non-specific, such as vomiting, diarrhea, sometimes abdominal pain, while in some cases, there is an absence of signs. Moreover, access to the pancreas for histopathological examination, considered to be the gold standard, is limited (Steiner et al. 2006, 2008, Van Den Bossche et al. 2010, Kalli et al. 2017). Thus, the diagnosis is generally made by associating the patient's history with clinical, laboratory, and imaging examination (Steiner et al. 2008, Kalli et al. 2017), however ultrasound examination is considered to have low sensitivity (Hess et al. 1998, Mansfield 2012). Serum amylase and total lipase activities also have low specificity and sensitivity (Steiner et al. 2008, Ferreira et al. 2008, Mansfield 2012). However, the specific canine pancreatic lipase (cPL) test is more sensitive and specific (Steiner et al. 2008, McCord et al. 2012, Silva \& Ponce 2015), with a reported specificity of $97.5 \%$ (NeilsonCarley et al. 2011, Neilso-Carley et al. 2011).

In veterinary medicine, the possibility of AP developing in patients with severe acute kidney disease has been poorly investigated. In medicine, there have been some reports of humans with kidney diseases (Masoero et al. 1996, Bruno et al. 2000, Golay \& Roychowdhary 2012, Hou et al. 2013, Tersant et al. 2018) showing increased serum activity of pancreatic enzymes and AP. The objective of this study was to evaluate laboratory parameters of dogs with severe ARF, to evaluate the likelihood of them developing AP, in relation to a negative energy balance and the degree of renal failure severity.

\section{MATERIALS AND METHODS}

We evaluated 40 dogs of different breeds and weights, neutered and non-neutered, male and female, owned by tutors in the metropolitan region of Belo Horizonte/MG, attending routine clinical examinations at the "Universidade Federal de Minas Gerais" (UFMG) Veterinary Hospital. These animals were divided into two groups: 30 in the ARF group (ARFG) and 10 in the control group (CG). The ARFG animals were diagnosed by ultrasound signs of kidneys with normal to increased dimensions, and which may or may not present diffuse hyperechogenicity of the parenchyma, as well as clinical and laboratory tests compatible with ARF. These dogs presented higher or equal to stage III ARF, according to the staging proposal of the International Renal Interest Society (Cowgill 2016). The CG comprised healthy animals, proven healthy by means of clinical and laboratory examinations (hemogram, biochemical profile, and urinalysis), besides an abdominal ultrasonographic examination.

The animals in the ARFG underwent blood sampling four times: at Time 1 (T1), within the first 24 hours (first day of hospitalization) after the complete clinical examination, ultrasound examination, and correction of hydration status, the first blood sample was collected. Time 2 (T2) was the third day of hospitalization; Time 3 (T3) was the fifth day of hospitalization, and Time 4 (T4) was the eighth day of hospitalization. This approach was used to gain a better understanding of the negative energy balance and of the kinetics of pancreatic enzymes in patients with severe renal failure. The animals in the CG underwent blood collection only once, after fasting for 12 hours.

Blood was collected by venipuncture of the external jugular with 5 -mL syringes and $25 \times 7$-mm needles. Urine collection was performed by ultrasound-guided cystocentesis using a 10 -mL syringe and $25 \times$ 7-mm needles. The examinations were performed in the "Laboratório de Patologia Clínica" of the "Escola de Veterinária" of UFMG. The samples were transferred to the laboratory soon after collection. Blood smears were immediately made for morphological evaluation of the cells and differential leukocyte count. Whole blood samples, in EDTA, were analyzed using an Icounter 5D Diagno ${ }^{\circledR}$ hematological analyzer (Belo Horizonte, Brazil). For serum biochemical analysis 
(urea, creatinine, ALT, AST, alkaline phosphatase, gamma-glutamyl transferase, glucose, amylase, total proteins, albumin, globulins, cholesterol, triglycerides, and beta-hydroxybutyrate), commercial kits (Biotecnica ${ }^{\circledR}$ - Biotécnica Ind. e Com. Ltda, Varginha, Brazil; and Randox $^{\circledR}$, Randox Laboratories Ltd, County Antrim, United Kingdom) were used, and the results obtained by spectrophotometric reading (Cobas Mira Plus ${ }^{\circledR}$, Roche, Brazil). The cPL test was performed using the Vcheck cPL, FV.0002 kit (ECO Diagnóstica LTDA, Brazil) for in vitro diagnosis, by the quantitative fluorescent immunoassay technique. Urinalysis involved measuring urinary density in a refractometer $\left(\right.$ Megabrix $\left.^{\circledR}\right)$, physical examination, a chemical examination by the Combur-Test $\left(\right.$ Roche $\left.^{\circledR}\right)$, and sedimentoscopy under an optical microscope (Nikon e200 ${ }^{\circledR}, 40 \times$ ).

In the animals in the ARFG, electrolytic replacement and maintenance were performed based on clinical signs and hemogasometry results, in addition to acid-base correction, when necessary, and with support treatment with antiemetics, gastric mucosa protectors, antibiotics, antihypertensives, among others, according to the individual clinical manifestations.

Statistical analyses were performed in R software version 3.5.1 ( R Core Team 2018). In all tests, a significance level of $5 \%$ was adopted. The normality and homoscedasticity of each variable was tested in its original unit and the logarithmic transformation was applied when necessary. Multivariate analysis was performed using Spearman's correlation matrix. The non-parametric Kruskal-Wallis test was applied to verify the differences in variables between groups. For multiple comparisons, the Wilcoxon test with Mann-Whitney's correction was used.

This study was approved by the Ethics Committee on the Use of Animals under protocol number 275/2018.

\section{RESULTS}

Of the 30 dogs in the ARFG, 16.7\% (5/30) were evaluated until T4 (8th day); $26.7 \%$ (8/30) until T3 (5th day); $33.3 \%$ $(10 / 30)$ until T2 (3rd day), and $23.3 \%(7 / 30)$ only until T1 (first $24 \mathrm{~h}$ ). The death rate was $73.3 \%$, most probably because the selected patients had severe ARF (grades III, IV, and V). Due to this high death rate, variables were compared between the animals in the ARFG and CG according to the results obtained at T1. For all variables, the Kruskal-Wallis global test was significant. In multiple comparisons, the CG always differed significantly from the ARFG (Fig.1-5, Table 1-4).

The mean serum urea and creatinine concentrations in the ARFG were 11 and 8.5 times higher, respectively, than those from the CG (Table 1). The mean serum concentrations of BHB were 6.6 times higher in the ARFG $(0.231 \mathrm{IU} / \mathrm{dL})$ than in the CG (0.035IU/dL) (Fig.1, Table 2). Triglyceride serum concentrations demonstrated similar behavior to those of BHB. The mean triglyceride serum concentrations of the animals

Table 1. Mean, median, standard deviation, and coefficient of variation of urea and creatinine serum concentrations (mg/dL) of healthy dogs (CG) and dogs with acute renal failure (ARFG) at T1

\begin{tabular}{|c|c|c|c|c|c|c|}
\hline Group & Mean & Median & Standard deviation & Coefficient of variation & 1st quartile & 3rd quartile \\
\hline & \multicolumn{6}{|c|}{ Urea $(\mathrm{mg} / \mathrm{dL})$} \\
\hline CG $(n=10)$ & 28.3 & $26.1^{\mathrm{b}}$ & 7.1 & $25 \%$ & 24.8 & 31.7 \\
\hline \multirow[t]{2}{*}{ ARFG $(n=30)$} & 312.1 & $311.5^{\mathrm{a}}$ & 92.8 & $30 \%$ & 255.3 & 387.5 \\
\hline & \multicolumn{6}{|c|}{ Creatinine $(\mathrm{mg} / \mathrm{dL})$} \\
\hline$C G(n=10)$ & 1.0 & $0.8^{\mathrm{b}}$ & 0.2 & $23 \%$ & 0.8 & 1.1 \\
\hline ARFG & 8.5 & $6.3^{\mathrm{a}}$ & 6.6 & $77 \%$ & 5.5 & 10.5 \\
\hline
\end{tabular}

$\overline{\mathrm{a}, \mathrm{b}}=$ Different letters in the same column represent statistically significant differences $(P<0.05)$; Reference values for healthy dogs: urea = 20-56mg/dL, creatinine $=0.5-1.5 \mathrm{mg} / \mathrm{dL}$ (Kaneko et al. 2009).
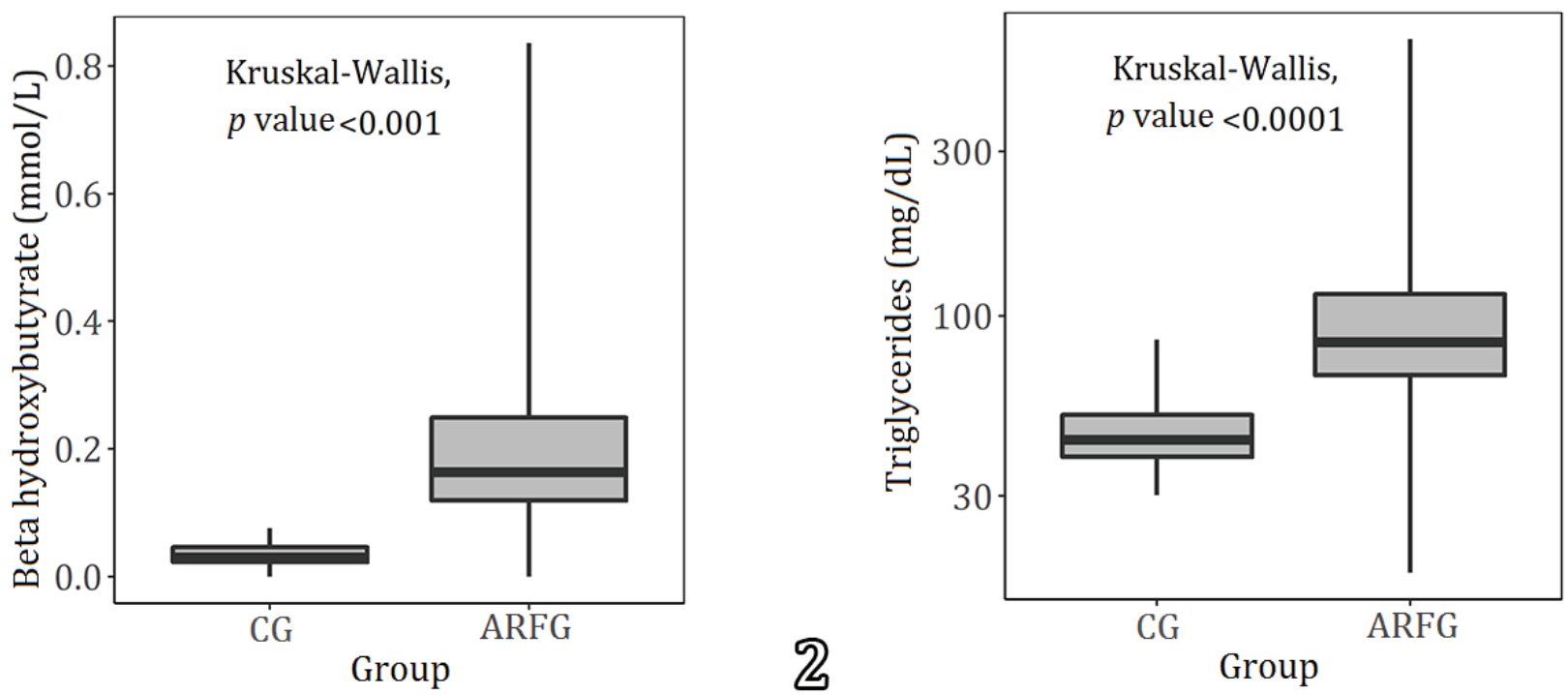

Fig.1-2. (1) Serum concentrations of beta-hydroxybutyrate (mmol/L) in the groups studied, at time 1 (T1), original scale. (2) Serum concentrations of triglycerides $(\mathrm{mg} / \mathrm{dL})$ of the studied groups, at $\mathrm{T} 1$, logarithmic scale. $\mathrm{CG}=$ group of healthy dogs (control, $\mathrm{n}=10$ ), $\mathrm{ARFG}=$ group of dogs with acute renal failure $(n=30)$. 
in the ARFG was 2.5 times higher than that in the CG; this difference was significant (Fig.2, Table 2). Of the 30 animals in the ARFG, eight (26.7\%) presented hypertriglyceridemia at some point in the study, considering the reference value of $150 \mathrm{mg} / \mathrm{dL}$ proposed by Kaneko et al. (2009). Of these eight dogs, seven (87.5\%) presented a cPL level $\geq 400 \mathrm{ng} / \mathrm{dL}$.

The mean amylase serum activity in patients in the ARFG was twice that of those in the CG (Fig.3, Table 3). The mean value of lipase serum activity differed among the groups, with that in the ARFG 16 times higher than that in the CG (Fig.4, Table 3,). In the ARFG, the mean value of cPL activity was $551.7 \mathrm{ng} / \mathrm{dL}$, which was 10 times higher than that in the CG (Fig.5, Table 3). Twenty-eight dogs in the ARFG had cPL activity measured at T1; of these, eight (28.6\%) had normal cPL (up to $200 \mathrm{ng} / \mathrm{dL}$ ), another eight $(28.6 \%$ ) had high cPL (between 201 and 399ng/dL), and 12 (42.8\%) had a value indicating AP (cPL $\geq 400 \mathrm{ng} / \mathrm{dL}$ ). Of these 28 dogs, six had Grade III, 15 had Grade IV dogs, and seven had Grade V ARF. Of the six Grade III dogs, two (33\%) presented serum activity of cPL within the reference range, while four $(67 \%)$ presented high cPL. Of the 15 grade IV dogs, four (26.7\%) had normal cPL, four (26.7\%) had high cPL, and seven (46.6\%) had cPL $\geq 400 \mathrm{ng} / \mathrm{dL}$. In the Grade V ARF subgroup, two of the seven dogs $(28.6 \%)$ had cPL within the reference range and five $(71.4 \%)$ had $\mathrm{cPL} \geq 400 \mathrm{ng} / \mathrm{dL}$. Eight of 16 animals (50\%) who had $\mathrm{cPL}<400 \mathrm{ng} / \mathrm{dL}$ at T1 had the values $\geq 400 \mathrm{ng} / \mathrm{dL}$ during

Table 2. Mean, median, standard deviation, and coefficient of variation of beta-hydroxybutyrate (BHB - mmol/L) and triglyceride serum concentrations (mg/dL) of healthy dogs (CG) and dogs with acute renal failure (ARFG) at T1

\begin{tabular}{|c|c|c|c|c|c|c|}
\hline Group & Mean & Median & Standard deviation & Coefficient variation & 1st quartile & 3rd quartile \\
\hline & \multicolumn{6}{|c|}{ BHB $(\mathrm{mmol} / \mathrm{L})$} \\
\hline CG $(n=10)$ & 0.035 & $0.030^{\mathrm{b}}$ & 0.026 & $74 \%$ & 0.023 & 0.046 \\
\hline ARFG $(n=30)$ & 0.231 & $0.163^{\mathrm{a}}$ & 0.194 & $84 \%$ & 0.120 & 0.249 \\
\hline$C G(n=10)$ & 47.1 & $43.7^{\mathrm{b}}$ & 14.9 & $32 \%$ & 39.0 & 51.7 \\
\hline $\operatorname{ARFG}(\mathrm{n}=30)$ & 118.5 & $83.8^{\mathrm{a}}$ & 111.1 & $94 \%$ & 67.4 & 115.7 \\
\hline
\end{tabular}

${ }_{\mathrm{a}, \mathrm{b}}$ Different letters in the same column represent statistically significant differences $(P<0.05)$; Reference values for healthy dogs: $\mathrm{BHB}=0.018-0.048 \mathrm{mmol} / \mathrm{L}$, triglycides $=32.2-62.0 \mathrm{mg} / \mathrm{dL}$ (Kaneko et al. 2009).

Table 3. Mean, median, standard deviation, and coefficient of variation of amylase (UI/L), lipase (UI/L), and cPL (ng/mL) serum activity of healthy dogs (CG) and those with acute renal failure (ARFG) at T1

\begin{tabular}{|c|c|c|c|c|c|c|}
\hline Group & Mean & Median & Standard deviation & Coefficient variation & 1st quartile & 3rd quartile \\
\hline & \multicolumn{6}{|c|}{ Amylase $(\mathrm{U} / \mathrm{L})$} \\
\hline$C G(n=10)$ & 665.7 & $600.3^{\mathrm{b}}$ & 219.5 & $33 \%$ & 496.3 & 768.1 \\
\hline \multirow[t]{2}{*}{ ARFG $(n=30)$} & 1379.2 & $1282.3^{\mathrm{a}}$ & 706.4 & $51 \%$ & 878.8 & 1681.2 \\
\hline & \multicolumn{6}{|c|}{ Lipase (U/L) } \\
\hline $\mathrm{CG}(\mathrm{n}=10)$ & 37.1 & $34.0^{\mathrm{b}}$ & 19.6 & $53 \%$ & 28.0 & 39.0 \\
\hline \multirow[t]{2}{*}{$\operatorname{ARFG}(n=30)$} & 590.1 & $134.0^{\mathrm{a}}$ & 1151.7 & $195 \%$ & 58.0 & 321.5 \\
\hline & \multicolumn{6}{|c|}{$\mathrm{cPL}^{\mathrm{c}}(\mathrm{ng} / \mathrm{mL})$} \\
\hline$C G(n=10)$ & 51.7 & $50.0^{\mathrm{b}}$ & 5.7 & $11 \%$ & 50.0 & 50.0 \\
\hline ARFG $(n=30)$ & 551.7 & $369.0^{\mathrm{a}}$ & 551.8 & $100 \%$ & 169.0 & 607.3 \\
\hline
\end{tabular}

${ }_{\mathrm{a}, \mathrm{b}}$ Different letters in the same column represent statistically significant differences $(P<0.05) ;{ }^{\mathrm{c}} \mathrm{cPL}=$ specific canine pancreatic lipase, ${ }^{\mathrm{c}} \mathrm{cPL}<200 \mathrm{ng} / \mathrm{dL}$ (Beall et al. 2011); Reference values for healthy dogs: amylase = 300-1500U/L, lipase = 15-250U/L (Kaneko et al. 2009).
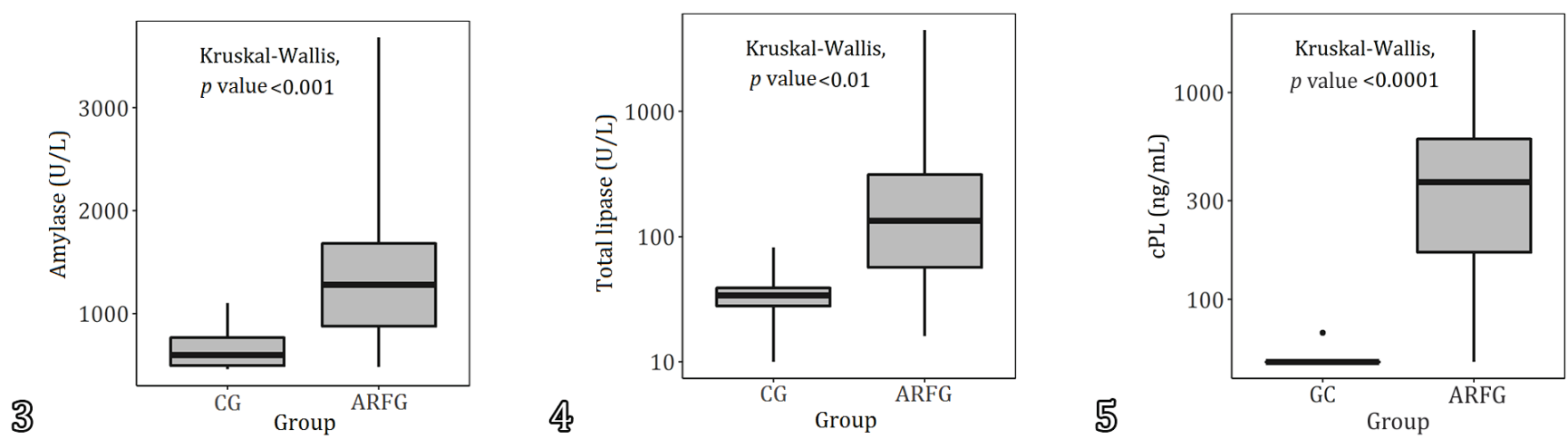

Fig.3-5. (3) Serum amylase concentrations (U/L) between the studied groups, at time 1 (T1), original scale. (4) Serum concentrations of total lipase (U/L) among the studied groups, at T1, logarithmic scale. (5) Serum activity of the canine pancreatic lipase (cPL) (ng/mL) among the studied groups, at T1, logarithmic scale. CG = group of healthy dogs (control, $n=10$ ), ARFG = group of dogs with acute renal failure $(n=30)$. 
ARF (Table 4). In addition, their serum BHB values (Table 4) were above the average CG value (Table 2) in at least one of the time-points of the study. When considering the values of serum CPL activity at all time-points, and not only at T1, 21 of the 30 dogs in the ARFG (70\%) presented $\mathrm{cPL} \geq 400 \mathrm{ng} / \mathrm{dL}$ at least at one of the time-points.

In multivariate analysis, positive correlations of serum concentrations of BHB with serum activity of cPL and total lipase, and between triglyceride serum concentrations and serum activity of cPL were observed. There was also a positive correlation between BHB and triglyceride serum concentrations and of these two factors with serum urea and creatinine. Additionally, serum urea and creatinine correlated positively with serum cPL activity (Fig.6).

\section{DISCUSSION}

The mean serum values of BHB, which were significantly higher in the ARFG than in the CG, support the concept that patients in ARF in this study were in a marked negative energy balance state, which was a predisposing factor to the development of AP. This relationship of negative energy balance with AP was also observed in the study by Hurrell et al. (2016), in which the blood concentration of BHB was significantly higher in dogs with AP than in sick dogs without AP, and than that of healthy dogs fasting for more than 10 hours. These results also proved that fasting prior to blood sampling in healthy animals does not significantly interfere with the serum concentration of BHB. Thus, serum BHB concentration can be a useful marker for monitoring patients with advanced ARF, and may signal the possibility of developing AP and alert carers to the need for nutritional support to minimize or prevent such complications.

The mean triglyceride serum concentration was two and a half times higher in patients in the ARFG than in patients in the $\mathrm{CG}$, which was in line with that mentioned by Wiesen et al. (2011). These authors suggested that increased triglyceride serum concentration in ARF may be a consequence of lipolysis, due to metabolic changes and decreased renal clearance of this compound. The mean triglyceride serum concentration of

Table 4. Serum activity of cPL and serum concentration of BHB of eight dogs in the group of patients with acute renal failure (ARFG), on day 1 (T1), day 3 (T2), day 5 (T3), and day 8 (T4) of hospitalization

\begin{tabular}{|c|c|c|c|c|c|c|c|c|}
\hline \multirow{2}{*}{ Patients } & \multicolumn{4}{|c|}{$\mathrm{cPL}^{\mathrm{a}}(\mathrm{ng} / \mathrm{mL})$} & \multicolumn{4}{|c|}{$\mathrm{BHB}^{\mathrm{b}}(\mathrm{mmol} / \mathrm{L})$} \\
\hline & T1 & $\mathrm{T} 2$ & $\mathrm{~T} 3$ & $\mathrm{~T} 4$ & $\mathrm{~T} 1$ & $\mathrm{~T} 2$ & T3 & $\mathrm{T} 4$ \\
\hline Patient 1 & 370 & 1466 & 1960 & $*$ & $*$ & 0.25075 & $*$ & $*$ \\
\hline Patient 2 & 368 & 1045 & 1270 & $>2000$ & 0.0532 & * & 0.07599 & 0.01521 \\
\hline Patient 3 & 205 & 254 & 213 & 574 & 0.07599 & 0.22796 & 0.08359 & 0.05319 \\
\hline Patient 4 & 380 & 570 & 567 & $*$ & 0.8358 & * & $*$ & * \\
\hline Patient 5 & 366 & 933 & 1109 & * & 0.22034 & 0.09879 & 0.22795 & * \\
\hline Patient 6 & $<50$ & $*$ & 1652 & $*$ & 0.15196 & * & 0.06839 & $*$ \\
\hline Patient 7 & 50 & 513 & $*$ & $*$ & 0.37993 & 0.28875 & * & $*$ \\
\hline Patient 8 & 170 & 1213 & $*$ & $*$ & 0.44071 & 0.09118 & $*$ & $*$ \\
\hline
\end{tabular}

* Value not measured due to death, euthanasia, requested discharge, or insufficient sample; ${ }^{\mathrm{a}} \mathrm{CPL}=$ canine lipase pancreatic, ${ }^{\mathrm{b}} \mathrm{BHB}=$ beta hydroxybutyrate; Reference values for healthy dogs: $\mathrm{cPL}<200 \mathrm{ng} / \mathrm{dL}$ (Beall et al. 2011), BHB = 0.018-0.048mmol/L (Kaneko et al. 2009).
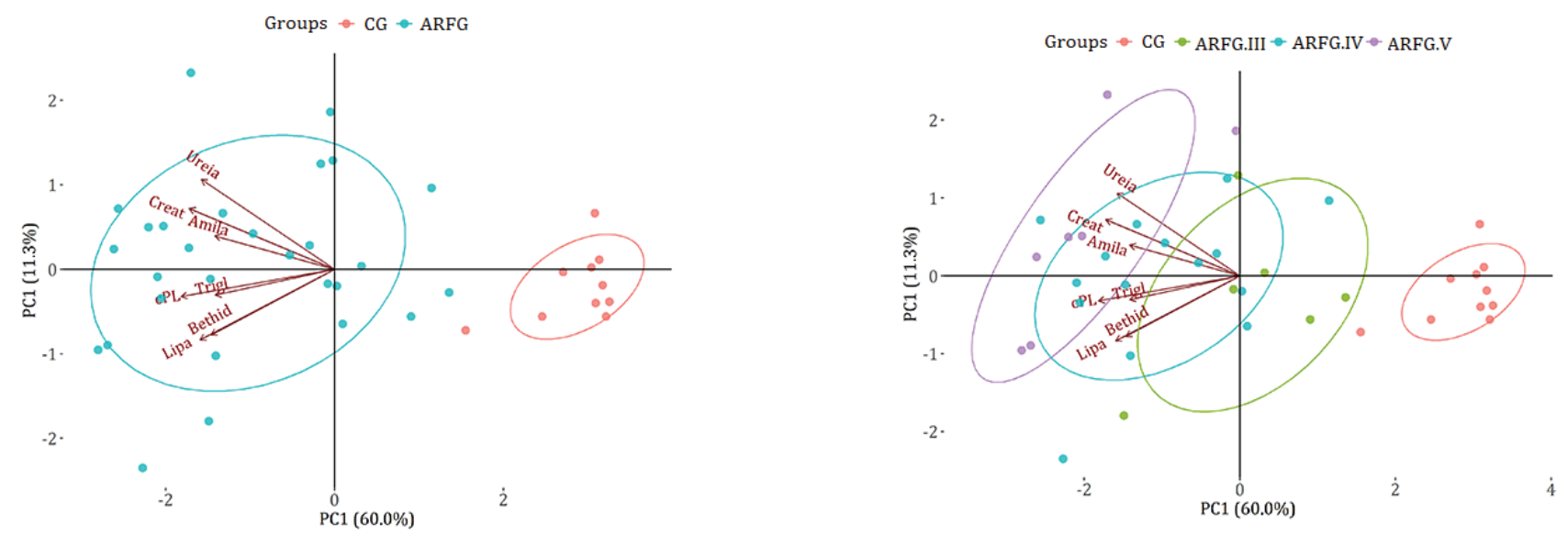

(6)

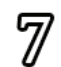

Fig.6-7. (6) Representation of the animals (pink and blue dots) belonging to each studied group (CG and ARFG) and their correlation with the variables shown in the graph. (7) Representation of the dogs (dots) belonging to CG (dots in pink) and subgroups ARFG. III = dogs in stage III of ARF (dots in green), ARFG. IV = dogs in stage IV of ARF (dots in blue), ARFG. V = dogs in stage V of ARF (points in lilac) and the correlation thereof with the variables (arrows). CG = group of healthy or control dogs (dots in pink), ARFG = group of patients with acute renal failure (dots in green, blue, and lilac), Ureia $=$ urea, Creat $=$ serum creatinine, Amila $=$ amylase, $c P L=c a n i n e ~ p a n c r e a t i c$ lipase, Lipa $=$ total lipase, Trigl $=$ serum triglycerides, Bethid $=$ serum beta-hydroxybutyrate . 
dogs in the CG $(n=10)$ of this study was similar to that found by Brunetto et al. (2011) in their control group $(n=10)$, i.e., $47.10 \pm 14.90 \mathrm{mg} / \mathrm{dL}$ and $56.41 \pm 19.80 \mathrm{mg} / \mathrm{dL}$, respectively. These values indicate that a triglyceride serum concentration above $150 \mathrm{mg} / \mathrm{dL}$ can be considered an appropriate cutoff point for hypertriglyceridemia (Kaneko et al. 2009).

The fact that seven of the eight patients in the ARFG, who were considered hypertriglyceridemic, presented serum cPL activity $\geq 400 \mathrm{ng} / \mathrm{dL}$, corroborates the concept that hypertriglyceridemia and AP are correlated, as observed also by Gan et al. (2006), Xenoulis \& Steiner (2010), and Radojković et al. (2014). In the study by Radojković et al. (2014), conducted in humans, hyperlipidemia was identified in 51\% of 47 patients with AP, and hypertriglyceridemia was predominant in these patients. Another six dogs in this study, although not presenting hypertriglyceridemia, showed increasing values of serum triglyceride levels, and five $(83.3 \%)$ of them had CPL $\geq 400 \mathrm{ng} / \mathrm{dL}$. The patient with the lowest range of triglyceride variation was the one whose cPL serum activity was <400ng/ $\mathrm{dL}$. The mechanism by which hypertriglyceridemia can trigger AP is not yet clear, but it is believed that pancreatic lipase, by hydrolyzing triglycerides, causes the release of fatty acids, which, depending on the amount, may be toxic to the pancreas (Xenoulis \& Steiner 2010).

The increase in the mean amylase serum activity in the ARFG was probably due to the decrease in its renal clearance, as Steiner et al. (2008) and Ferreira et al. (2008) have already reported. This is not the case with $\mathrm{cPL}$, as demonstrated by Steiner et al. (2009) and Köster et al. (2015), who showed that the decrease in the glomerular filtration rate did not cause a decrease in cPL renal clearance, since there was no increase in its serum activity. The mean serum activity of total lipase in the ARFG, many times higher than that in the CG, suggested a higher sensitivity of lipase than of amylase for signaling the possibility of AP. Ferreira et al. (2008), on the other hand, observed hyperlipasemia in critically ill human patients, who did not necessarily have AP, particularly in those with a long length of hospital stay, fever, and use of parenteral nutrition. This denotes the low specificity of total lipase. These observations support the use of cPL tests as an important tool for the diagnosis of AP in dogs (Steiner et al. 2009). The positive correlation between cPL serum activity values with those of amylase and total lipase, verified in this study, was also observed by Köster et al. (2015).

The values recommended by the manufacturer of the CPL test (Vcheck cPL - FV.0002 - ECO Diagnóstica Ltda, Brazil) are as follows: normal, up to 200ng/dL; high, values between $201 \mathrm{ng} / \mathrm{dL}$ and 400ng/dL, and confirming AP, $\geq 400 \mathrm{ng} / \mathrm{dL}$. The higher serum activity of cPL in dogs with more severe ARF demonstrated a higher chance of AP developing in these animals. In terms of the 12 patients who already had $\mathrm{cPL} \geq 400 \mathrm{ng} / \mathrm{dL}$ at T1, two explanations are possible: one would be the possibility that ARF had triggered AP prior to hospitalization, and the other would be the existence of AP before ARF occurred. In these patients, therefore, it was not possible to state that AP occurred as a consequence of ARF. However, in eight other animals, the serum activity of $\mathrm{CPL}$ was $<400 \mathrm{ng} / \mathrm{dL}$ at $\mathrm{T} 1$, but reached $\geq 400 \mathrm{ng} / \mathrm{dL}$ at other timepoints. It is understood that, in these animals, AP occurred as a consequence of severe ARF, with the possibility that the negative energy balance status caused the development of such complications. This negative energy balance condition was demonstrated by the serum values of BHB which, at least at one of the time-points evaluated, was higher than the mean values of the CG.

It is important to highlight that despite the attempt to supply the patients with enteral nutrition, due to the nausea and/or vomiting occurrence it was not possible to supplement them in their total caloric requirement. Another point to be highlighted is that none of the medications used during the hospitalization had a known potential to trigger AP according to Pereira et al (2011).

To facilitate an overview of the behavior of the variables and their correlations with each other and with the groups studied, we present a graphical representation in Figure 6 and 7. Two graphs were created, in which the location of the variables (arrows) and the animals (dots) are the same. The first graph (Fig.6) highlights the animals of the two groups ( $\mathrm{CG}=$ dots in pink, ARFG = dots in blue) and the correlation of these groups with the variables. All arrows represented in Figure 6 and 7 form a grouping of variables that correlate positively with each other, since they are facing in the same direction, to the left of the y-axis. One can also evaluate the arrangement of the animals in each group in this multivariate space. The pink dots represent the healthy animals (CG) and the blue dots indicate the animals with ARF (ARFG). The two groups are delimited within a perimeter that encompasses most of the animals (dots) corresponding to each group. Observing the positioning of the arrows in the groups, it can be seen that ARFG presented higher values of the studied variables, opposite to the CG, which is further away and shows arrows in the opposite position. The group whose arrows have their point towards its perimeter (ARFG), presents a positive correlation with the variables they represent. The longer the length of the arrow, the more strongly positively correlated is the relevant variable to the group to which it belongs. This is exemplified by the arrows for urea, creatine, cPL, and lipase in the ARFG, meaning that they were the variables that increased the most in this group, followed by amylase, BHB, and triglycerides. The second graph (Fig.7) shows the subgroups of the ARFG, according to the stage of $A R F$ severity, and the CG. Based on the relative positioning of the ARFG III, ARFG IV, and ARFG V subgroups and considering the arrows, it is clear that, the more severe the degree of ARF, the greater the possibility of developing AP.

The positive correlation between the serum concentrations of BHB and triglycerides and the correlation of these factors with serum urea and creatinine prove the occurrence of a negative energy balance with mobilization of fats in the ARF condition. The serum concentrations of creatinine and urea, which correlated positively with the serum activity of $\mathrm{cPL}$, demonstrated the possibility that ARF triggered AP, in agreement with the behavior of the enzyme kinetics of $\mathrm{cPL}$ (Table 4). It is likely that the positive correlation of serum creatinine and urea with cPL occurred indirectly; that is, the higher the serum concentration of urea and creatinine, the more critically ill the patient is in terms of ARF. The more severe the patient's hypermetabolism and inappetence, the higher is the negative energy balance and, therefore, the greater is the chance of triggering AP. The positive correlation between BHB serum concentrations and the serum activity of $\mathrm{cPL}$ and total lipase reinforce this concept of negative 
energy balance predisposing to AP. The positive correlation between creatinine serum concentrations and BHB confirms the occurrence of a negative energy balance in ARF and the positive correlation between triglyceride serum concentration and serum activity of cPL reinforces hypertriglyceridemia as another triggering factor of AP.

Finally, the increase in serum concentrations of urea, creatinine, $\mathrm{CPL}$, and total lipase variables, followed by BHB, triglycerides, and amylase, from the ARFG to the CG (Fig.6) shows an interrelation between the markers of renal insufficiency (urea and creatinine), AP (cPL, total lipase), and negative energy balance (BHB and triglycerides). Thus, the clinician, and particularly the intensivist, must be attentive to the use of tools that are not yet common in the routine monitoring of patients with severe ARF, such as BHB and cPL. The serum dosage of BHB, identifying a negative energy balance state, contributes to warning of the need for adequate energy supply, helping to prevent AP. The serum activity of cPL, in turn, identifies an AP condition that has already developed, or it can point to a tendency for the development of pancreatitis when the tests are performed in series during the hospitalization. It should be considered, therefore, that the use of these tools for the identification of the AP concomitant with ARF increases the chance of a better prognosis for the patient with severe ARF.

\section{CONCLUSION}

Acute pancreatitis (AP) is a condition present in dogs with severe acute renal failure (ARF). The negative energy balance in these patients is a predisposing condition to $\mathrm{AP}$, and the greater the degree of ARF, the greater the predisposition to AP.

Conflict of interest statement.- The authors declare that there is no conflict of interest.

\section{REFERENCES}

Beall M.J., Cahill R., Pigeon K., Hanscom J. \& Huth S.P. 2011. Performance validation and method comparison of an in-clinic enzyme-linked immunosorbent assay for the detection of canine pancreatic lipase. J. Vet. Diagn. Invest. 23(1):115-119. <https://dx.doi.org/10.1177/104063871102300120> $<$ PMid:21217040>

Brunetto M.C., Nogueira S., Sá F.C., Peixoto M., Vasconcelos R.S., Ferraudo A.J. \& Carciofi A.C. 2011. Correspondence between obesity and hyperlipidemia in dogs. Ciência Rural 41(2):266-271. <https://dx.doi.org/10.1590/ S0103-84782011005000004>

Bruno M.J., Van Westerloo D.J., Van Dorp W.T., Dekker W., Ferwerda J., Tytgat G.N.J. \& Schut N.H. 2000. Acute pancreatitis in peritoneal dialysis and haemodialysis: Risk, clinical course, outcome, and possible aetiology. Gut 46(3):385-389. <https://dx.doi.org/10.1136/gut.46.3.385><PMid:10673301>

Carvalho M.B. 2015. Acute renal failure, p.1364-1393. In: Jericó M.M., Neto J.P.A. \& Kogika M.M. (Eds), Tratado de Medicina Interna de Cães e Gatos. Roca, Rio de Janeiro.

Claus P., Gimenes A.M., Castro J.R., Mantovani M.M., Kanayama K.K., Simões D.M.N. \& Schwartz D.S. 2017. Blood lactate concentration in diabetic dogs. Can. Vet. J. 58(8):817-822. <PMid:28761186>

Cowgill L. 2016. Grading of acute kidney injury. International Renal Interest Society, UK. 9p. Available at <http://www.iris-kidney.com/pdf/4_ldcrevised-grading-of-acute-kidney-injury.pdf $>$ Accessed on June 6, 2020.

Ferreira M., Coelho R., Luzio J. \& Coutinho P. 2008. Elevation of lipase and amylase in the critically ill patient: Retrospective study. Revta Bras. Ter. Intens. 20(4):362-369. <https://dx.doi.org/10.1590/S0103-507X2008000400008>
Gan S.I., Edwards A.L., Symonds C.J. \& Beck P.L. 2006. Hypertriglyceridemiainduced pancreatitis: a case-based review. World J. Gastroenterol. 12(44):7197-7202. <https://dx.doi.org/10.3748/wjg.v12.i44.7197> <PMid:17131487>

Golay V. \& Roychowdhary A. 2012. Acute pancreatitis in chronic kidney disease - a common but often misunderstood combination. Renal Failure 34(10):1338-1340.<https://dx.doi.org/10.3109/0886022X.2012.718951> $<$ PMid:23002785>

Gorman L., Sharkey L.C., Armstrong P.J., Little K. \& Rendahl A. 2016. Serum beta hydroxybutyrate concentrations in cats with chronic kidney disease, hyperthyroidism, or hepatic lipidosis. J. Vet. Intern. Med. 30(2):611-616. <https://dx.doi.org/10.1111/jvim.13826> <PMid:26773702>

Hess R.S., Saunders H.M., Van Winkle T.J., Shofer F.S. \& Washabau R.J. 1998. Clinical, clinicopathologic, radiographic, and ultrasonographic abnormalities in dogs with fatal acute pancreatitis: 70 cases (1986-1995). J. Am. Vet. Med. Assoc. 213(5):665-670. <PMid:9731261>

Hou S.-W., Lee Y.-K., Hsu C.-Y., Lee C.-C. \& Su Y.-C. 2013. Increased risk of acute pancreatitis in patients with chronic hemodialysis: a 4-year followup study. PLoS One 8(8):e71801. <https://dx.doi.org/10.1371/journal pone.0071801><PMid:23977145>

Hurrell F.E., Drobatz K.J. \& Hess R.S. 2016. Beta-hydroxybutyrate concentrations in dogs with acute pancreatitis and without diabetes mellitus. J. Vet. Intern. Med. 30(3):751-755. <https://dx.doi.org/10.1111/jvim.13947> $<$ PMid:27075106>

Kalli I.V., Adamama-Moraitou K.K., Patsika M.N., Pardali D., Steiner J.M., Suchodolski J.S., Menexes G., Brellou G.D. \& Rallis T.S. 2017. Prevalence of increased canine pancreas-specific lipase concentrations in young dogs with parvovirus enteritis. Vet. Clin. Pathol. 46(1):111-119.<https://dx.doi. org/10.1111/vcp.12447><PMid:28125171>

Kaneko J.J., Harvey J.W. \& Bruss M.L. 2009. Appendix VIII Blod analyte reference values in small and in some laboratory animals, p.889-895. In: Ibid. (Eds), Clinical Biochemistry of Domestic Animals. 6th ed. Academic Press, San Diego.

Köster L.S., Steiner J.M., Suchodolski J.S. \& Schoeman J.P. 2015. Serum canine pancreatic-specific lipase concentrations in dogs with naturally occurring Babesia rossi infection. J. S. Afr. Vet. Assoc. 86(1):E1-E7. <https://dx.doi. org/10.4102/jsava.v86i1.1297> <PMid:26304138>

Li R., Mugford A. \& Humm K. 2013. Acute kidney injury in dogs and cats 2. Management, treatment and outcome. In Practice 35(6):302-316. $<$ https://dx.doi.org/10.1136/inp.f3640>

Mansfield C. 2012. Acute pancreatitis in dogs: advances in understanding, diagnostics, and treatment. Top Companion Anim. Med. 27(3):123-132. <https://dx.doi.org/10.1053/j.tcam.2012.04.003> <PMid:23148853>

Masoero G., Bruno M., Gallo L., Colaferro S., Cosseddu D. \& Vacha G.M. 1996. Increased serum pancreatic enzymes in uremia: Relation with treatment modality and pancreatic involvement. Pancreas 13(4):350-355. <https:// dx.doi.org/10.1097/00006676-199611000-00004><PMid:8899795>

McCord K., Morley P.S., Armstrong J., Simpson K., Rishniw M., Forman M.A., Biller D., Parnell N., Arnell K., Hill S., Avgeris S., Gittelman H., Moore M., Hitt M., Oswald G., Marks S., Burney D. \& Twedt D. 2012. A multi-institutional study evaluating the diagnostic utility of the spec $\mathrm{CPL}$ and SNAP(R) cPL in clinical acute pancreatitis in 84 dogs. J. Vet. Intern. Med. 26(4):888-896. <https://dx.doi.org/10.1111/j.1939-1676.2012.00951.x><PMid:22676337>

Neilson-Carley S.C., Robertson J.E., Newman S.J., Kutchmarick D., Relford R., Woosley K. \& Steiner J.M. 2011. Specificity of a canine pancreas-specific lipase assay for diagnosing pancreatitis in dogs without clinical or histologic evidence of the disease. Am. J. Vet. Res. 72(3):302-307. <https://dx.doi org/10.2460/ajvr.72.3.302><PMid:21355731>

Palomba H. \& Okada V.M. 2010. Nutritional support in acute renal injury, p.149-154. In: Homsi E. \& Palomba H. (Eds), Acute Kidney Injury in the Critically ill. Atheneu, São Paulo. 
Pereira B., Gonçalves R., Caldeira A., Pais T.P., Pereira E., Tristan J., Sousa R. \& Banhudo A. 2011. Pancreatite aguda induzida por fármacos: caso associado ao perindopril e revisão da literatura. J. Port. Gastroenterol. 18:34-39.

R Core Team 2018. R: a language and environment for statistical computing. R Foundation for Statistical Computing, Vienna, Austria. Available at <https://www.R-project.org/> Accessed on January 14, 2019.

Radojković M., Stojanović M., Radojković D., Jeremić L., Stanojević G., Damnjanović Z. \& Stevanović G. 2014. Hyperlipidemia in acute pancreatitis: concomitant disorder or a cause? FU Med. Biol. 16(2):57-60.

Ross L. 2011. Acute kidney injury in dogs and cats. Vet. Clin. N. Am., Small Anim. Pract. 41(1):1-14. <https://dx.doi.org/10.1016/j.cvsm.2010.09.003> <PMid:21251508>

Neilso-Carley S.C., Robertson J.E., Newman S.J., Kutchmarick D., Relford R. Woosley K. \& Steiner J.M. 2011. Specificity of a canine pancreas-specific lipase assay for diagnosing pancreatitis in dogs without clinical or histologic evidence of the disease. Am. J. Vet. Res. 72(3):302-307. <https://dx.doi. org/10.2460/ajvr.72.3.302> <PMid:21355731>

Silva R.D. \& Ponce F.G. 2015. Pancreatitis, p.3187. In: Jericó M.M., Neto J.P.A. \& Kogika M.M. (Eds), Tratado de Medicina Interna de Cães e Gatos. Roca, Rio de Janeiro. 7047p.

Steiner J.M., Newman S.J., Xenoulis P., Woosley K., Suchodolski J., Williams D. \& Barton L. 2008. Sensitivity of serum markers for pancreatitis in dogs with macroscopic evidence of pancreatitis. Vet. Ther. 9(4):263-273. <PMid:19177331>

Steiner J.M., Rutz G.M. \& Williams D.A. 2006. Serum lipase activities and pancreatic lipase immunoreactivity concentrations in dogs with exocrine pancreatic insufficiency. Am. J. Vet. Res. 67(1):84-87. <https://dx.doi. org/10.2460/ajvr.67.1.84> <PMid:16426216>

Steiner J.M., Teague S.R., Lees G.E., Willard M.D., Willians D.A. \& Ruaux C.G. 2009. Stability of canine pancreatic lipase immunoreactivity concentration in serum samples and effects of long-term administration of prednisone to dogs on serum canine pancreatic lipase immunoreactivity concentrations. Am. J. Vet. Res. 70(8):1001-1005. <https://dx.doi.org/10.2460/ajvr.70.8.1001> <PMid:19645581>

Tersant M., Kwon T., Macher M.A., Maisin A., Deschênes G. \& Niel O. 2018. Hypernatremia and acute pancreatitis in chronic kidney disease: back to the salt mines. Questions. Pediatr. Nephrol. 33(7):1155-1156. <https:// dx.doi.org/10.1007/s00467-017-3821-2> <PMid:29067525>

Van Den Bossche I., Paepe D. \& Daminet S. 2010. Acute pancreatitis in dogs and cats: pathogenesis, clinical signs and clinicopathologic findings. Vlaams Diergeneeskundig Tijdschrift. 79:13-22.

Veado J.C.C., Santos K.K.F. \& Anjos T.M. 2014. Injúria renal aguda, p.23-31. In: Santos K.K.F. (Ed.), Guia Prático de Nefrologia em Cães e Gatos. L.F. Livros, Rio de Janeiro.

Wiesen P., Overmeire L.V., Delanaye P., Dubois B. \& Preiser J.C. 2011. Nutritional disorders during acute renal failure and renal replacement therapy. JPEN J. Parenter. Enteral Nutr. 35(2):217-222. <https://dx.doi. org/10.1177/0148607110377205><PMid:21378251>

Xenoulis P.G. \& Steiner J.M. 2010. Lipid metabolism and hyperlipidemia in dogs. Vet. J.183(1):12-21. <https://dx.doi.org/10.1016/j.tvjl.2008.10.011> <PMid:19167915> 